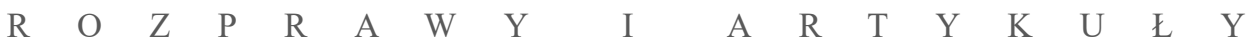

\title{
Marek Dybizbański
}

Uniwersytet Opolski

\section{KSZTAŁT $Z$ BOÓJCÓW SCHILLERA NA SCENACH POLSKICH XIX WIEKU - PRZEKLAD JANA NEPOMUCENA KAMIŃSKIEGO}

Schiller's Robbers on Polish Stages in the $19^{\text {th }}$ Century: The Translation by Jan Nepomucen Kamiński 


\begin{abstract}
Abstrakt: W teatrze lwowskim pod dyrekcją Jana Nepomucena Kamińskiego Zbójcy Friedricha Schillera byli częścią teatralnej ofensywy romantyzmu, ostrożnej w warunkach cenzury i rozciągniętej w czasie, ale konsekwentnie realizowanej nie tylko w polityce repertuarowej, lecz także w doborze środków inscenizacyjnych, przede wszystkim aktorskich. Przekład Kamińskiego z 1817 (lub wcześniejszy) na długie lata ustalił kształt niemieckiego arcydzieła epoki „,burzy i naporu” dla polskich teatrów, wpłynął też na zasady scenicznego opracowania późniejszych tłumaczeń. Odpis zachowany w Bibliotece Teatru Lwowskiego pochodzi z 1864. Kamiński oparł przekład na skróconej i zmienionej niemieckojęzycznej wersji dramatu przygotowanej w 1781 dla teatru w Mannheim i tam wydanej, choć zachowany odpis wskazuje na użycie również redakcji kanonicznej, znanej z pierwodruku i kolejnych autoryzowanych przez Schillera wydań. Ten późny odpis zawierający ślady wielu ingerencji i pewnie również ingerencje zatarte przez pracę kopisty - podsuwa oryginalne rozwiązania inscenizacyjne, mogące pochodzić od pierwszego thumacza i adaptatora scenicznego.
\end{abstract}

Słowa kluczowe: Friedrich Schiller, Jan Nepomucen Kamiński, rękopis, inscenizacja dziewiętnastowieczna

\begin{abstract}
In the Lviv theater headed by Jan Nepomucen Kamiński, Friedrich Schiller's The Robbers was part of a theater campaign of Romanticism; even though it was cautious due to censorship and long-winded, the Lviv entrepreneur produced an important staging not only considering the selection of the play itself, but also in staging choices and especially in acting ones. Kamiński's 1817 (or earlier) translation determined the shape of the German Sturm und Drang masterpiece for Polish theaters for many years. It also influenced the way later translations were staged. A copy preserved in the Lviv Theatre Library in Katowice dates from 1864. Although Kamiński's translation was based on an abridged and revised German version of the drama, prepared in 1781 for a theater in Mannheim and published there, the analyzed copy also contains references suggesting the use of the canonical edition, known from the original printing of the drama and its subsequent editions authorized by Schiller. This late copy, bearing the traces of numerous interventions, though some were probably obliterated by the copyist, suggests original staging solutions that may have been made by the first translator and stage adaptor himself. (Trans. Z. Ziemann)
\end{abstract}

Keywords: Friedrich Schiller, Jan Nepomucen Kamiński, manuscript, 19th-century staging 
W

polskim teatrze pierwszej połowy XIX wieku nie było artysty bardziej predestynowanego do przygotowania przekładu, scenicznego opracowania i wreszcie inscenizacji Schillerowskiego arcydzieła epoki „burzy i naporu” niż Jan Nepomucen Kamiński (1777-1855), długoletni antreprener sceny lwowskiej (1809-1842). Wśród jego lekturowych inspiracji znajdują się prace filozofów niemieckiej szkoły idealizmu transcendentalnego (Hegla i Schellinga) ${ }^{1}$, wśród powiązań towarzyskich zwraca uwagę bliska znajomość między innymi z Maurycym Mochnackim ${ }^{2}$, wśród inscenizacyjnych zasług wysuwają się na czoło przekłady oraz inscenizacje tragedii Shakespeare'a i właśnie Schillera ${ }^{3}$. Na tę śmiałość repertuarową Kamiński mógł sobie pozwolić dzięki mniejszemu niż w Warszawie obciążeniu teatru lwowskiego tradycją klasycznego repertuaru i klasycznego aktorstwa. Poprzedzający lwowską antrepryzę okres prowadzenia zespołu teatralnego w Kamieńcu Podolskim (1803-1805) uchodzi za swoiste repertuarowe i warsztatowe laboratorium ${ }^{4}$, a ogłoszone w drugim tomie „Haliczanina” z 1830 Myśli o umnictwie dramatycznym (zawierające ponoć raczej zestaw pobożnych życzeń Kamińskiego niż wykład jego zrealizowanej metody ${ }^{5}$ ) z postulatami dogłębnej analizy dzieła dramatycznego oraz gry zespołowej stanowią swoistą prowokację wobec ówczesnej praktyki scenicznej. Romantycznie zorientowaną wrażliwość lwowskiego antreprenera ukształtowały dzieła Schillera, czytane od lat młodzieńczych w oryginale. Zdaniem Barbary Lasockiej Kamiński „wręcz utożsamiał się $\mathrm{z}$ niemieckim poetą $\mathrm{w}$ sferze odczuwania i interpretacji świata,

1 Zob. B. Lasocka, Dramatopisarstwo Jana Nepomucena Kamińskiego, [w:] Dramat i teatr postanisławowski, red. D. Ratajczak, Wrocław 1992, s. 75.

2 Zob. ibidem, s. 76.

3 Zob. ibidem, s. 108-120.

4 Zob. K. Kurek, Wokół „Myśli o umnictwie dramatycznem”, „Poznańskie Studia Polonistyczne”, Seria Literacka nr V(XXV), Poznań 1998. W artykule Kurka opublikowano fragmenty tego tekstu, całość ukazała się w opracowaniu A. Marszałek, zob. J. N. Kamiński, Myśli o umnictwie dramatycznym, [w:] Polskie piśmiennictwo teatralne XIX wieku, t. 1: W stronę praktyki-podręczniki sztuki aktorskiej, wybór i oprac. D. Kosiński, A. Marszałek, A. Wanicka, współpr. A. Narębska, Kraków 2007

5 Zob.: B. Lasocka, Aktorzy w teatrze Kamińskiego, „Pamiętnik Teatralny” 1967 z. 1, s. 93; K. Kurek, op. cit., s. 217. 
w poetyckiej wrażliwości, a nawet w twórczych zamiarach i ambicjach"6. Lektura Schillera zaważyła także na jego percepcji i scenicznych opracowaniach dramatów Shakespeare'a - wpływała czasem na ich kształt, jak w przypadku Makbeta, tłumaczonego z Schillerowskiej adaptacji ${ }^{7}$, częściej na wizję świata i projektowany styl odbioru przekładu, sygnalizowany niekiedy poprzez dedykacje ${ }^{8}$. Z czasem zakwestionowano wartość translatorskiej strategii Kamińskiego ${ }^{9}$, trzeba jednak pamiętać, że jego przekłady powstawały w czasie, gdy w Warszawie sztuki Shakespeare'a grywano w thumaczeniach $\mathrm{z}$ francuskich lub niemieckich przeróbek, które nie tylko „przycinały” pierwowzory do klasycystycznej ramy trzech jedności, ale i nierzadko łagodziły lub eliminowały co drastyczniejsze sceny i co okrutniejsze postaci; zdarzało się nawet, że zgodnie z estetyką preromantycznej dramy zastępowały końcową tragiczną katastrofę sentymentalnym pojednaniem ${ }^{10}$.

Kamińskiego przekład Zbójców datowany jest najczęściej na rok $1817^{11}$, choć czasami na $1819^{12}$, a bywa, że i $1805^{13}$ - rok śmierci Schillera. Za życia poety wystawiano dramat $\mathrm{w}$ zmienionej i skróconej wersji, której sporządzenie już po pierwszym wydaniu tekstu (w 1781, bez nazwiska autora) wymusił przed mann-

6 B. Lasocka, Dramatopisarstwo..., op. cit., s. 117.

7 Tezę, którą Lasocka przedstawia jako „niezwykle ponętne przypuszczenie” (ibidem, s. 113), Kurek uznaje już za pewną (op. cit., s. 216).

$8 \mathrm{Na}$ zaczerpniętą z poezji Schillera dedykację w wydaniu przekładu Hamleta z 1805 wskazuje B. Lasocka, eadem, Dramatopisarstwo..., op. cit., s. 117 (analiza tekstu przekładu na podstawie unikatowego egzemplarza ze zbiorów Biblioteki Jagiellońskiej, ibidem, s. 108-112).

9 Wśród krytycznych ocen dorobku Kamińskiego A. Marszałek przywołuje zapis w encyklopedii Orgelbranda (t. 8): „Przekłady jego z Shakespeare'a, Calderona itd., jako dokonywane z niemieckiego, nie mają wartości”, cyt. za: eadem, Wstęp, [w:] J. N. Kamiński, Myśli o umnictwie..., op. cit., s. 105.

${ }_{10}$ Tak było z Hamletem w przekładzie Bogusławskiego na podstawie przeróbki Schrödera, z Otellem w jednej z wersji opracowania Ducisa czy z dramą Merciera Groby Werony, wzorowaną na Romeo i Julii. Zob. m.in.: M. Szyjkowski, Dzieje nowożytnej tragedii polskiej. Typ szekspirowski, Kraków 1923; A. Żurowski, Szekspiriady polskie, Warszawa 1967.

11 Jako pierwszy teatralny sukces dramatu Schillera w Polsce Szyjkowski wskazał lwowską inscenizację z 7 XI 1817, zręcznie omijając kwestię autorstwa przekładu (wymienił wprawdzie osobę „wielbiciela i znawcy Schillera”, ale - jakby na wszelki wypadek - tylko jako światłego dyrektora, który odważnie wprowadził na scenę dramat „,burzy i naporu”), idem, Schiller w Polsce. Studium historycznoporównawcze, Kraków 1915, s. 109. W roli „wielbiciela i tłumacza Schillera” Kamiński wystąpił tu parę stron dalej, w osobnym ustępie poświęconym lwowskiej serii przedstawień Schillerowskich, ibidem, s. 115-118. W zestawieniu repertuarowym Lasockiej podana jest ta sama data jako początek lwowskiej kariery dramatu z odnotowanym nazwiskiem Kamińskiego jako tłumacza, eadem, Teatr lwowski w latach 1800-1842, Warszawa 1867, s. 380.

12 Zob. Bibliografia literatury polskiej Nowy Korbut. Oświecenie, t. 5, oprac. E. Aleksandrowska et al., Warszawa 1967, s. 58.

13 W pierwszej połowie roku 1805 (dwa lata po klęsce warszawskiej premiery Zbójców, zob. M. Szyjkowski, op. cit., s. 108) tragedię Schillera wystawił w Kamieńcu Podolskim zespół działający pod kierownictwem Kamińskiego (zob. J. Komorowski, Polskie życie teatralne na Podolu i Wołyniu do 1963 roku, Wrocław 1985, s. 17). Kurek autorstwo przekładu przypisuje Kamińskiemu, idem, op. cit., s. 215-216. 
heimską premierą (13 stycznia 1782) dyrektor tamtejszego teatru, Wolfgang Heribert von Dalberg, i którą od razu wypuścił w druku wydawca Christian Schwan ${ }^{14}$. W następnych latach wznawiano zarówno pierwotną, kanoniczną postać tekstu ${ }^{15}$, jak i wersję skróconą, zwaną tu dalej roboczo redakcją mannheimską ${ }^{16}$. Ostatecznie przyjdzie odwoływać się do obu wersji, jako że przekład Kamińskiego - w tej postaci, jakiej dostarcza zachowany egzemplarz - oparty jest na redakcji mannheimskiej ${ }^{17}$, choć w szczegółach nawiązuje też do kanonicznej.

Ten wczesny przekład zachował się w znacznie późniejszym, pochodzącym z 1864, teatralnym odpisie Biblioteki Teatru Lwowskiego w zbiorach Biblioteki Śląskiej pod sygnaturą $801^{18}$. Zdigitalizowany i dostępny dziś w Śląskiej Bibliotece Cyfrowej ${ }^{19}$ - został ostatnio przywołany w monografii Doroty Jarząbek-Wasyl i Barbary Maresz:

Manuskrypt, opatrzony rzadko spotykaną pieczęcią „Dyrekcja Teatru AM”, pochodzi niewątpliwie z czasów dyrekcji lwowskiej i lwowsko-krakowskiej Adama Miłaszewskiego, kiedy to Zbójców wystawiono dla występującego gościnnie Jana Królikowskiego. Być może podstawą tego rękopisu był dawny egzemplarz z teatru Jana Nepomucena Kamińskiego, z czasów premiery w 1817 r. Na niektóre role (np. Karola i Hermana) naklejono fragmenty thumaczenia Michała Budzyńskiego, którego to przekładu zaczęto używać we Lwowie w latach 80. XIX w. Tak więc egzemplarz z czasów pierwszej antrepryzy Miłaszewskiego na pewno był wykorzystywany także później²0.

14 Zob. Klasycyzm niemiecki. Życie i twórczość Goethego i Schillera, wybór i oprac. G. Albrecht i J. Mittenzwei, przeł. J. Buras et al., Warszawa 1970, s. 138.

15 Wersja kanoniczna w oryginale cytowana wg wydania: Die Räuber. Ein Schauspiel von Schiller, Tübingen 1805 (dalej: Die Räuber...).

16 Cytowana w artykule wg wydania: Die Räuber: ein Trauerspiel von Friedrich Schiller. Neue für die Mannheimer Bühne verbesserte Original-Auflage, Mannhaim 1798 (dalej: Neue [...] Original-Auflage).

17 Naprowadzenie na ten trop zawdzięczam dr Marioli Szydłowskiej, której niniejszym składam za to serdeczne podziękowanie.

18 Także przy jego identyfikacji nie obyło się bez pewnych komplikacji. Publikacja Dramat obcy $w$ Polsce 1765-1965. Premiery - druki-egzemplarze (t. 2 [L-Z], red. J. Michalik, S. Hałabuda, K. Stepan, Kraków 2004, s. 179) wymienia ten odpis na pierwszym miejscu wśród zachowanych egzemplarzy teatralnych ,polskich” Zbójców, ale błędnie identyfikuje jako przekład Michała Budzyńskiego (pwdr. 1850) - mimo że już strona tytułowa rękopisu rozstrzyga sprawę jednoznacznie: „Przełożył Jan Nep. Kamiński”.

19 Zbójcy. Tragedya Fryderyka Szyllera w 5u aktach przełożyt Jan Nep. Kamiński. Przepisano w Krakowie 1864 r, rkps, Biblioteka Teatru Lwowskiego w zbiorach Biblioteki Śląskiej, sygn. 801, https://sbc.org.pl/dlibra/show-content/publication/edition/26410?id=26410 [dostęp: 10 VI 2019] (dalej: BTLw 801); wg opisu w Śląskiej Bibliotece Cyfrowej: „zawiera: liczne kreślenia, poprawki, doklejone fragmenty tekstu, wpisy suflerskie (Lwów, 1874) oraz wklejony list Konstantego Skrzyńskiego do Mieczysława Sachorowskiego (z 3 VIII 1884) w sprawie występów śpiewaczki Heleny Herman w Krakowie". Cytaty z tego uzupełnianego doklejkami egzemplarza podawane sa w transliteracji, dlatego nie modernizowano pisowni i zachowano charakterystyczne dla egzemplarzy rękopiśmiennych podkreślenie $\mathrm{w}$ tekście pobocznym.

20 D. Jarząbek-Wasyl, B. Maresz, Archiwum teatru XIX wieku. Ludzie, dokumenty, historie, Kraków 2019, s. 295. 
Data sporządzenia odpisu w naturalny sposób kieruje uwagę w stronę gościnnych występów Królikowskiego w Krakowie i Lwowie w 1864. Według zestawień repertuarowych we Lwowie 26 i 31 października grano przekład Kamińskiego $^{21}$, w Krakowie zaś - 17 marca i 15 listopada - tłumaczenie Budzyńskiego ${ }^{22}$. Na podejrzenie użycia w listopadzie przekładu Kamińskiego naprowadza jednak data 10 listopada $1864 \mathrm{w}$ adnotacji zamykającej omawiany dokument ${ }^{23}$ :

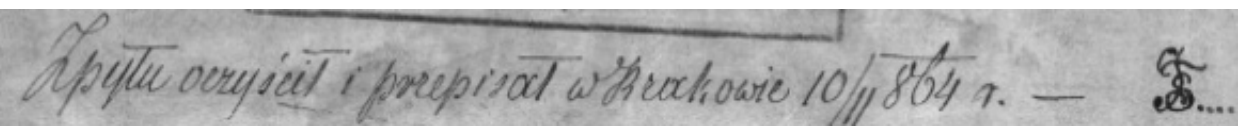

Czy możliwe, by w listopadzie przepisano tekst w przekładzie innym niż ten, który był podstawą przedstawienia odegranego parę miesięcy wcześniej? Nie można wykluczyć, że dokonano podmiany tekstu, choć trudno znaleźć powód takiej decyzji, jeśli w marcu użyto tłumaczenia Budzyńskiego wykorzystywanego z powodzeniem w następnych latach ${ }^{24}$. $\mathrm{Na}$ inny ostrożny domysł naprowadza jedna $\mathrm{z}$ recenzji marcowego przedstawienia, w której krakowski korespondent lwowskiego „Dziennika Literackiego” przeprowadził druzgocącą krytykę wystawionego przekładu:

Dodać w końcu musimy, że thumaczenie i przerobienie oryginału jest najniegodziwszem. [...] Całe najpiękniejsze ustępy powypuszczano, a natomiast wyrażeń barbarzyńskich bez miary. I tak, kiedy Karol Moor ojca swego z wieży poznaje, przerażony okropnością zbrodni krzyczy: „S z k a r a d n y fa n to m i e!” Więc ojciec jego, którego on kocha bez granic, jest mu w takiej zwłaszcza chwili „szkaradnym”? Albo gdy Szwajcer każąc wziąc pełnomocnika rządu, [...] woła: „Zaszyjcie go w w i epr zo w ą skórę i rzućcie go p sow i (sic). Tak samo wyrażenie

21 A. Marszałek, Repertuar teatru polskiego we Lwowie 1864-1875, Kraków 2003, s. 21.

22 J. Got, E. Orzechowski, Repertuar teatru krakowskiego 1845-1865, Warszawa 1974, s. 344 i 351.

23 Identyfikację dwóch pionowych kresek jako arabskiej jedenastki, nie zaś rzymskiej dwójki (czyli oznaczenie listopada, a nie lutego) opieram na rozpoznaniu M. Szydłowskiej, powołującej się na zwyczaj stosowania w datowaniu teatralnych odpisów cyfr arabskich.

24 Poświadczają to już samym bogactwem wpisów dodawanych przy różnych okazjach dwa późniejsze, oparte na przekładzie Budzyńskiego, egzemplarze Biblioteki Teatru Lwowskiego:

1) Zbójcy. Tragedya w 11-tu odstonach Schillera, rkps, Biblioteka Teatru Lwowskiego w zbiorach Biblioteki Śląskiej, sygn. 1158, https://sbc.org.pl/dlibra/show-content/publication/edition/54877?id=54877, [dostęp: 1 II 2020] (dalej: BTLw 1158); wg opisu w Śląskiej Bibliotece Cyfrowej: „,zawiera liczne wpisy i kreślenia suflerskie (Lwów, 1887, 1888 - występ gościnny Bolesława Leszczyńskiego, 1892, 1896, 1897, 1898, 1899), obsadę (Lwów, 1892)”, wskazany thumacz: Michał Budzyński.

2) Zbójcy. Trajedyja w 5 aktach (11 obrazach) Schillera. Tłómaczone z niemieckiego M. Budzyńskiego. W obrazie 9tym pieśń zbójców z muzyka St. Moniuszki, rkps, Biblioteka Teatru Lwowskiego w zbiorach Biblioteki Śląskiej, sygn. 1780, https://sbc.org.pl/dlibra/show-content/ publication/edition/26524?id=26524 [dostęp: 1 II 2020] (dalej: BTLw 1780); wg opisu w Śląskiej Bibliotece Cyfrowej: „zawiera: liczne kreślenia i wpisy suflerskie, obsadę (Kraków, 1888)”. 
„Lucyper” w najtragiczniejszych użyte miejscach, a jednak w polskim języku w powszechnym używaniu i u ludu, „Lucyper” używany bywa tylko w komicznych zajściach, tymczasem jak na złość kilkakrotnie mówiono „Lucyper”. Otóż wszystkie takie niedostatki powinna dyrekcja sama, lub przez zastępcę ad hoc koniecznie usuwać, inaczej nie łudźmy się, że scena jest kolebką, piastunem i przechowywaczem polskiego języka ${ }^{25}$.

Konkluzję można by równie dobrze odnieść do języka i stylu samej recenzji, ale mniejsza o to. Ważne, że cytowane frazy nie odpowiadają thumaczeniu ani Budzyńskiego, ani Kamińskiego. U Budzyńskiego w chwili uwolnienia starego Moora Karol tylko „cofa się z przestrachem”26, rozpoznawszy głos ojca - zgodnie $\mathrm{z}$ kanoniczną wersją dramatu ${ }^{27}$. Teatralne opracowania tego przekładu czasem przewidują w tym miejscu okrzyk: „Boże!”28, wprowadzony też do odpisu przekładu Kamińskiego - w miejscu skreślonego zwrotu „Okropny widoku”29, istotnie odpowiadającego edycji mannheimskiej, w której Karol woła: „Entsetzliches Blendwerk" "30, czyli w dosłownym, słownikowym tłumaczeniu: „straszne mamidło”, co właściwie wydaje się bliższe owemu nieszczęsnemu „fantomowi” z recenzji niż „widokowi” z przekładu Kamińskiego. Wiadomo z następnej, wspólnej obu niemieckim redakcjom, „hamletowskiej” kwestii Karola („Duchu starego Moora" ${ }^{31}$ ), że początkowo bierze on wyjście ojca z lochu za spotkanie z duchem. Albo zatem tekstu dla przedstawienia odegranego w marcu 1864 dostarczył jakiś jeszcze inny, niezbyt wyrafinowany przekład redakcji mannheimskiej, albo ta brutalizacja języka była skutkiem modyfikacji pochopnie wprowadzanych - możliwe, że przez samych wykonawców - do któregoś z przekładów uznanych i od dawna w teatrach używanych (nie można też wykluczyć celowego fałszerstwa ze strony nieżyczliwego recenzenta, który korzystając z parawanu zawodnej pamięci mógł umyślnie zwulgaryzować przywołaną kwestię w celu lepszego uzasadnienia swego oburzenia). Tego rodzaju świadectwa pozwalają na sformułowanie przypuszczenia, choć nie na bezsporną identyfikację użytego tekstu.

Zachowany egzemplarz przekładu Kamińskiego zawiera ślady wielu ingerencji - skreślenia, uzupełnienia, doklejane paski lub nawet całe karty, zapisane różnymi charakterami pisma. Poprawki wprowadzane więc prawdopodobnie przy różnych okazjach, w różnych latach, na potrzeby rozmaitych inscenizacji.

25 Korespondencje, „Dziennik Literacki” $1864 \mathrm{nr} 16$, s. 200. Rozstrzelenia w tym i kolejnych cytatach - M. D.

26 F. Schiller, Zbójcy. Dramat w 5 aktach, przeł. M. Budzyński, Złoczów [1924], s. 151 (dalej: Budzyński).

27 „MOOR (springt erschrocken zurück) Das ist meines Vaters Stimme!”, Die Räuber..., s. 165.

28 BTLw 1158, op. cit., k. 101v.

29 BTLw 801, op. cit., k. 40r.

30 Neue [...] Original-Auflage, op. cit., s. 129.

31 BTLw 801, op. cit., k. 40r. 
Niektóre wklejki zastępują poszczególne kwestie odpowiednikami z przekładu Budzyńskiego, inne podają warianty z tamtym przekładem rozbieżne, ale niewykluczone, że w jakiejś przynajmniej części powielające pierwotny zapis tłumaczenia Kamińskiego (w jednym miejscu widać to bardzo wyraźnie ${ }^{32}$ ). Zmiany wprowadzane na dodanych kartach, ręką inną niż ręka pierwszego kopisty, mają zapewne pochodzenie teatralne, ale w szczegółach niewiadome. W rezultacie nie sposób stanowczo rozstrzygać o proweniencji pojedynczych oryginalnych rozwiązań, których przypisanie Kamińskiemu trzeba by za każdym razem obwarować szeregiem zastrzeżeń. $Z$ jednej strony zachowane egzemplarze teatralnych adaptacji przekładu Budzyńskiego pokazują, że dla przekształceń tłumaczonego tekstu w teatrze nie było właściwie żadnych ograniczeń. $Z$ drugiej strony przekład Budzyńskiego, oparty na redakcji kanonicznej i ogłoszony drukiem w 1850, przygotowywany był z myślą o wydawnictwie i dopiero stamtąd trafił do teatru, Kamiński zaś swój przekład przeznaczał od początku dla sceny - jak wcześniej do niej adresowana była redakcja mannheimska.

\section{UKŁAD SCEN}

W edycji mannheimskiej niewiele w sumie scen wycięto w całości (wspólne czytanie Biblii przez hrabiego i Amalię w akcie II, wspomnienia i zapowiedzi Karola w obecności Kosińskiego w pobliżu rodowej siedziby Moorów w akcie IV), ale znalazły się wśród nich sceny o istotnym znaczeniu dla rozwoju akcji (rozpoznanie Karola przez starego sługę Daniela i niezrealizowana decyzja rozpoznanego o szybkim odjeździe w akcie IV), a przede wszystkim dla filozoficznej warstwy dramatu (dyskusja Franciszka z pastorem Moserem w akcie V). W ogólnym jednak bilansie w skróconej redakcji pozostało więcej filozofii niż sensacji, co mogłoby wydać się decyzją ryzykowną w teatrze dążącym do zapełnienia widowni. W tragedii Schillera jednak wątek sensacyjny realizuje się właściwie nie w obrębie akcji scenicznej, lecz w obszernych epickich wtrętach. Bez obaw zatem o frekwencję śmiało wycięto opowieści Spiegelberga o złożeniu zeznań obciążających „miejscowego eskulapa”, a następnie o zrabowaniu klasztoru i zgwałceniu zakonnic, dalej jego instrukcję werbowania nowych zbójców, a także odpowiedź Razmanna opisującą ,janosikowy" model zbójectwa uprawiany przez Karola Moora. Uchowała się wprawdzie historia odbicia spod szubienicy Rollera poprzez podpalenie miasta, lecz w wersji mocno okrojonej,

32 Wpis na wklejce $\mathrm{w}$ górnej części strony 41r obejmuje partię tekstu pierwotnie rozpoczętą $\mathrm{u}$ dołu strony poprzedniej (40v) i rozwijaną na stronie następnej na powierzchni objętej wklejką. Po wprowadzeniu korekty partia ze strony $40 \mathrm{v}$ - niezaklejona - została przekreślona, dzięki czemu widać, że na wklejce znalazł się tekst na pewnym odcinku literalnie z poprzedniej strony przepisany. 
pozbawionej wątków grabieży kościoła, splądrowania sklepu i ofiar w ludziach (dzieciach, kobietach, starcach i kalekach). Większość skrótów poczynionych w redakcji mannheimskiej zadomowiła się w teatrze na stałe, o czym świadczą teatralne egzemplarze z lat osiemdziesiątych XIX wieku. One też dowodzą, że i do przedstawień realizowanych według przekładu Budzyńskiego - który przecież opierał się na redakcji kanonicznej - wprowadzano niektóre z mannheimskich rozwiązań konstrukcyjnych ${ }^{33}$.

W segmentacji tekstu edycja mannheimska przestrzega klasycznej zasady wejść i wyjść postaci, na którą tłumacz nałożył zgodny z wersją kanoniczną, romantyczny podział wedle zmian miejsca akcji sygnalizowanych zmianą dekoracji. Na przykład akt II, który w oryginale składa się z trzech scen (w pokoju Franciszka, w sypialni starego Moora i w Czeskich Lasach), u Kamińskiego liczy dziewięć scen i wśród nich dwie „zmiany”. Natomiast akt I, pierwotnie przez Schillera podzielony również na trzy sceny (sala w zamku Moorów, karczma w Saksonii, pokój Amalii w zamku Moorów), w przekładzie obejmuje scen sześć (bo tyle razy zmienia się personalny skład uczestników rozgrywanej sytuacji), ale zmianę tylko jedną, gdyż - zgodnie z edycją mannheimską - sceny oznaczone w wersji kanonicznej jako druga i trzecia zostały zamienione miejscami, a dialog Amalii z Franciszkiem (przeniesiony z jej pokoju do komnaty ze sceny pierwszej) uczyniono bezpośrednią kontynuacją akcji związanej z odczytaniem staremu Moorowi sfałszowanego listu. W realizacji przedstawienia pozwoliło to zaoszczędzić jedną zmianę otwartą. Drugi przypadek przeniesienia sceny wynikał już chyba z głębszego zamysłu konstrukcyjnego dla akcji dramatycznej: moment, w którym Amalia dowiaduje się od Hermana, że stary Moor i jej ukochany Karol nadal żyją, w wersji kanonicznej przypadający na koniec pierwszej sceny III aktu, w edycji mannheimskiej trafił w środek aktu IV, pomiędzy ciąg scen związanych z przebywającym już w zamku Moorów tajemniczym gościem, w którym mieszkańcy nie domyślają się Karola. Konkretnie wypada ten dialog między monologiem Amalii a jej spotkaniem z nierozpoznanym kochankiem, więc wejście Hermana psuje wprawdzie nastrój sceny, ale za to bohaterka odbiera wiadomość w momencie, w którym mogłaby zrobić z niej użytek - tyle że nie robi, nawet w edycji mannheimskiej. O ile jednak tam doszło tylko do pogubienia sensów, o tyle w thumaczeniu zepsuto jeszcze wizję sceniczną, zatrzymując na scenie Hermana:

33 Oba dostępne w Śląskiej Bibliotece Cyfrowej teatralne opracowania przekładu Budzyńskiego z lat osiemdziesiątych (zob. przypis 24) powielają na przykład mannheimski wzór konstrukcji aktu I, ale jednocześnie oba zachowują kanoniczne usytuowanie rozmowy Hermana z Amalią, zaś scenę rozpoznania Karola Moora przez starego sługę jeden (BTLw 1780) zawiera, drugi (BTLw 1158) nie. Różnią się też zakończeniami. 
Herman. Sie leben.

(er stürzt hinaus)

Zwölfter Auftritt

Räuber Moor (durch den Bogengang)

Amalia. (die wie versteinert gestanden, fährt

halb rasend auf) Karl lebt! (sie will ihm

nachstürzen, und stützt - auf den Räuber).

R. Moor. Wohin so stürmisch, mein Freulein ${ }^{35}$ ?
Herman. Oni obadwaj żyją!

Amalia. O nieba!... co mówisz?... Mój Karol żyje?..

(wybiega).

\section{Scena 4}

Dawni, Karol (wstrzymując ją w progu).

Karol. Dokądże tak nagle pani ${ }^{34}$ ?

Zarówno więc z sytuacji, jak z didaskaliów wynika, że dręczony wyrzutami wspólnik Franciszka staje się milczącym uczestnikiem rozmowy kochanków. Dziwny to u wprawnego inscenizatora - lecz nie tak zaskakujący u pracującego w pośpiechu tłumacza - przypadek reżyserskiego niedopatrzenia.

\section{INSTRUKCJE WYKONAWCZE}

Poza tym potknięciem Kamiński bardzo starannie reżyseruje w swoim przekładzie spektakl przeznaczony dla przeciętnie wyposażonego dziewiętnastowiecznego teatru. Tekst przewiduje zmiany otwarte, ale pomija w didaskaliach na przykład konie pasące się nieopodal obozowiska zbójców nad Dunajem w akcie III (występują zarówno w redakcji kanonicznej, jak i w mannheimskiej), zaś do obozu zbójców w Czeskich Lasach w akcie II Karol Moor nie wjeżdża na koniu (jak w obu wersjach niemieckich), lecz zwyczajnie w chodzi (ściśle biorąc - mówi „wchodząc" ${ }^{36}$, co oryginalny Schillerowski bohater czyni „zeskakując z konia”) ${ }^{37}$. Jednak nie tylko techniczne możliwości teatru regulowały takie zmiany. W tej samej scenie, zaraz po wejściu Karol Moor w każdym innym wariancie tekstu „rzuca się na ziemię"38, a u Kamińskiego - „s i a da"39, gdy jednocześnie Roller, uratowany od szubienicy w zgiełku wywołanym przez pożar miasta, po swoim wejściu - wbrew wszystkim innym redakcjom - ,ściąga z szyi kawałki podartego sznurka"40.

34 BTLw 801, op. cit., k. 37r.

35 Neue [...] Original-Auflage, op. cit., s. 114.

36 BTLw 801, op. cit., k. 22r.

37 Dosłownie: „,vom Pferd springend”, Neue [...] Original-Auflage, op. cit., s. 64.

38 Budzyński, op. cit., s. 79, w obu redakcjach niemieckich: „,wirft sich auf die Erde”, Neue [...] Original-Auflage, s. 64.

39 BTLw 801, op. cit., k. 22r.

40 Ibidem. 
Inwencja thumacza $\mathrm{w}$ zakresie ruchu scenicznego najśmielej bodaj objawiła się w scenie omdlenia starego Moora po odebraniu fałszywej wieści o śmierci Karola i kłótni z Franciszkiem (akt II). Warto zauważyć, że w edycji mannheimskiej ta scena nie występuje, Franciszek bowiem po wyjściu już nie wraca, a stary Moor opada omdlały na fotel w obecności Amalii, której krzyk zamyka cały „obraz”41. Widzowie w Mannheim, podobnie jak czytelnicy wydanej wersji skróconej, nie wiedzieli zatem - aż do chwili odkrycia miejsca uwięzienia Moora w akcie IV - co naprawdę stało się ze starym hrabią. Tłumacz (albo ktoś, kto przed rokiem 1864 pracował w teatrze na jego tekście), który inaczej pokierował wyjściami postaci - czyli zamiast Franciszka wcześniej usunął ze sceny Amalię - musiał opierać się na jakimś wydaniu (lub przekładzie) redakcji kanonicznej i do niej wprowadził dodatkowe wskazówki dotyczące ruchu, później skreślone:

Hrabia. Bazyliszku! Wyrzutku!.. oddaj mi mego Karola! Nieeh eię przekleństwo moje śeiga!... Oddaj mi, oddaj mego Karola!

Franciszek. (sadza go gwaltownie w fotel) Stareze! (gdy starzee kona z uśmiechem wpatruje sie w twarz jego) Umarł! - A jeźli[!] to sen tylko?.. zapewne - zapewne, to tylko sen, sen i śmierć - to bliźnięta Zmienimy cię śnie pożądany i nazwiemy cię śmiercią..! (klaszeze dtonie) ( eho

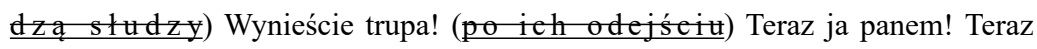
ujrzycie Franciszka bez maski i okropność was przejmie ${ }^{42}$.

Skreślenia w odpisie świadczą, że gdzieś w dziejach wystawień dramatu po 1864 odrzucono ów reżyserski dodatek thumacza, który wygląda jednak na ustępstwo wobec konwencji klasycystycznej ze znamienną dla niej zasadą niepokazywania zwłok na scenie - ustępstwo obustronne i trochę groteskowo połowiczne: stary Moor wszak jeszcze żyje, więc w zasadzie może przyjąć pozycję „trupa”, ale niech się Franciszek przynajmniej nie chełpi swoim triumfem nad jego bezwładnym ciałem.

Cały zresztą tekst przekładu sprawia wrażenie pisanego $\mathrm{z}$ większym niż w oryginale uwrażliwieniem na wizerunek i pozycję hrabiego. Poprzedzający omówioną scenę dialog między starym Moorem i przebranym za posła Hermanem - z udziałem Franciszka i Amalii ${ }^{43}$ - uzyskał przebieg spokojniejszy niż w oryginale - tym razem poprzez częściową eliminację tekstu pobocznego. Schiller (w obu niemieckich redakcjach) projektuje w didaskaliach coraz gwałtowniejsze reakcje hrabiego, tak oddane w wiernym przekładzie Budzyńskiego:

${ }^{41}$ Zob. Neue [...] Original-Auflage, op. cit., s. 59.

42 BTLw 801, op. cit., s. 21r, tym razem transliteracja linearna nie uwzględnia poprawek wprowadzonych w odpisie inną ręką, dla omawianego zagadnienia nieistotnych, za to przy pomocy spacji oznaczono partie tekstu niewystępujące w innych redakcjach.

${ }_{43}$ W wersji kanonicznej do rzekomej śmierci Moora dochodzi po scenie wspólnego z Amalią czytania Biblii (akt II, sc. 2), edycja mannheimska usuwa wątek wspólnej lektury, ale pozostawia tych dwoje na scenie, rezygnując z powtórnego wejścia Franciszka. 
MOOR z okropnym krzykiem włosy wyrywajac Moje przekleństwo na śmierć go zawiodło, wyzionął ducha w rozpaczy.

$[\ldots]$

MOOR $s$ a a p iac $t$ warz i $k r z y c z a c$ Biada, biada! Moje przekleństwo w śmierć go zagnało, wyzionął ducha w rozpaczy!

$[\ldots]$

MOOR bijac się po piersi i czole To był anioł, klejnot nieba! Przekleństwo, przekleństwo, zniszczenie, przekleństwo na mnie samego! Jam ojciec, co zamordował wielkiego syna. Mnie on kochał do śmierci; mnie żeby pomścić, biegi na bój i śmierć! O okropnie, okropnie ${ }^{44}$ !

W wersji Kamińskiego kierunek reakcji starego Moora jest odwrotny - gestykulacja zmierza ku wyciszeniu, aby tym mocniej mógł wybrzmieć końcowy okrzyk:

Hrabia ( $\underline{\text { w rozpaczy rwac sobie włosy }}$ ) Moje przekleństwo wygnało go na śmierć!..

$[\ldots]$

Hrabia (w rozpaczy) Biada mi biada! Moje przekleństwo wygnało go na śmierć...!

$[\ldots]$

Hrabia. Przekleństwo! przekleństwo niech padnie na mnie samego, ja to jestem, który zamordowałem; kochał mnie aż do śmierci... o żmijo! Poczwaro ${ }^{45}$ !

Projekcja scenicznego gestu potwierdza rozpoznanie Agnieszki Marszałek, zgodnie z którym Kamiński uważał, ,że słowa mówią same za siebie i nie potrzebują dublującej ilustracyjności gestu czy gry twarzą" ${ }^{46}$. Jednocześnie przytoczone przykłady pokazują, że pogląd ten nie był zakorzeniony w szkole aktorstwa klasycznego, z charakterystycznym dlań brakiem zaufania do pozawerbalnych środków wyrazu ${ }^{47}$. W scenie omdlenia starego Moora gest nie dubluje wszak słowa, lecz dopełnia je, natomiast przy serii okrzyków intensyfikacji jednego kodu towarzyszy wygaszanie aktywności drugiego, dzięki czemu rozpacz bohatera, przeżywana coraz mniej ,teatralnie”, z nieopanowanego wybuchu emocji przechodzi stopniowo w precyzyjnie ukierunkowany wyrzut, a postać hrabiego zyskuje przy okazji więcej powagi i dostojeństwa.

Nie można stwierdzić, by taka była ogólna tendencja całego przekładu. Kamiński wprawdzie przesuwa niekiedy akcenty, lecz zasadniczo postępuje za redakcją mannheimską z jej wyrazistszym niż pierwotnie skontrastowaniem po-

${ }_{44}$ Budzyński, op. cit., s. 61-63. W tekście niemieckim odpowiednio: 1) ,gräßlich schreiend, sich die Haare ausraufend"; 2) ,schreiend, sein Gesicht zerfleischend” 3) ,schlägt mit geballter Faust wieder Brust und Stirn" (Die Räuber..., op. cit., s. 70-72; Neue [...] Original-Auflage, op. cit., s. 56-58). Ten sam układ gestów powtarzają teatralne odpisy oparte na przekładzie Budzyńskiego (BTLw 1158, op. cit., k. 53r-56r; BTLw 1780, op. cit., k. 44v-46v).

45 BTLw 801, op. cit., k. 20r-20v.

46 A. Marszałek, Wstęp, op. cit., s. 100.

47 Zob. Z. Raszewski, Zasada NIG, [w:] idem, Trudny rebus. Studia i szkice z historii teatru, Wrocław 1990. 


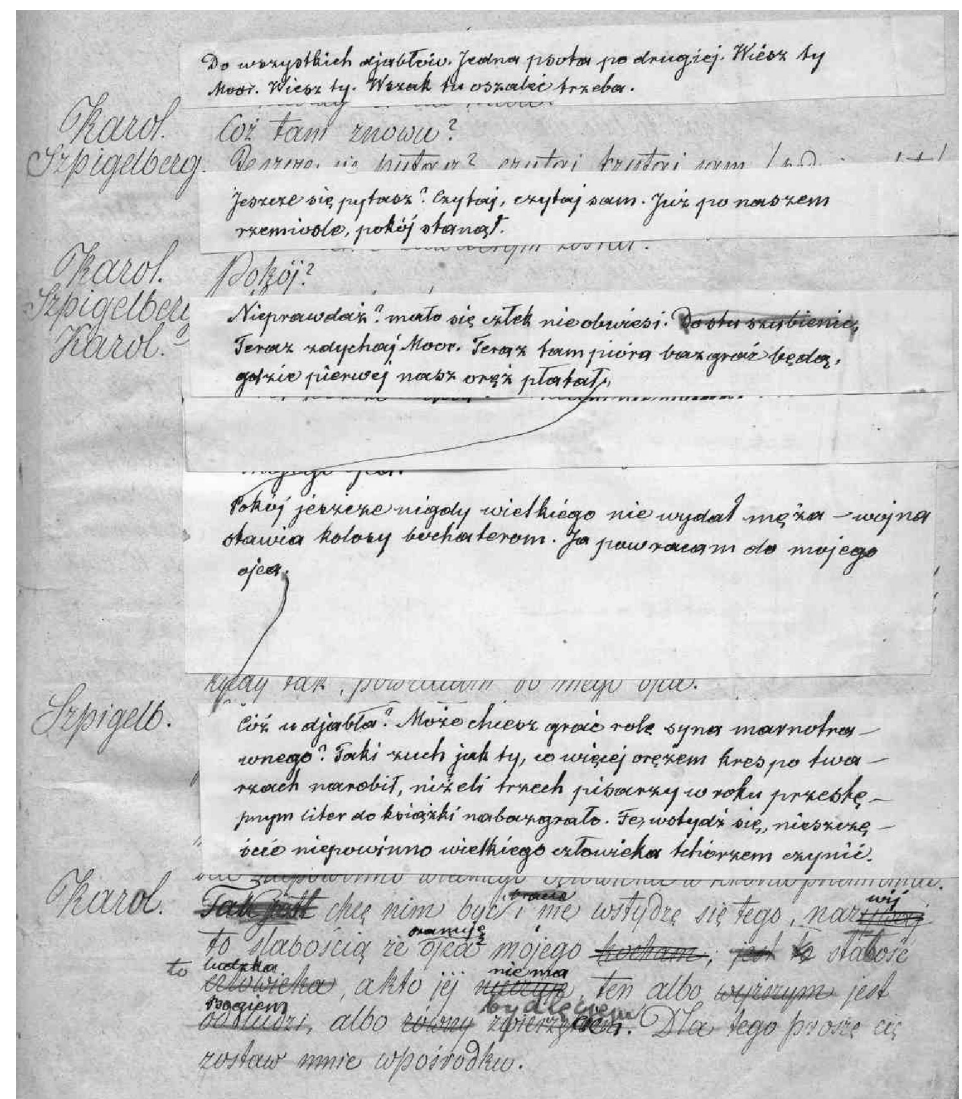

Fragment karty 11r odpisu przekładu J. N. Kamińskiego, Biblioteka Śląska, BTLw, sygn. 801

staci, obliczonym na wyostrzenie ich scenicznego wizerunku, co wpływa także na charakter konfliktów.

\section{POSTACI I KONFLIKTY}

Najwyższą bodaj cenę zapłacił Karol Moor, już w redakcji mannheimskiej sprowadzony nieledwie do kreacji młodocianego awanturnika. Z kwestii Franciszka w pierwszej scenie dramatu usunięto fragment o młodzieńczych lekturach obu braci ${ }^{48}$, a na początku sceny w karczmie saksońskiej Karol nie zaczyna od refleksji nad dziełem Plutarcha. W odpisie lwowskim jego wypowiadane w tym miejscu przemyślenia,

48 W przekładzie Budzyńskiego: „Czyżem nie przeczuwał, gdy on przygody Juliusza Cezara, Aleksandra Wielkiego i innych niesfornej duszy pogan wolał odczytywać aniżeli życie pokutującego Tobiasza?" (Budzyński, op. cit., s. 8). 
spisane z przekładu Budzyńskiego, ale w formie monologowej, z pominięciem replik rozmówcy, zostały dodane na osobnej karcie (zapisanej innym charakterem pisma) i w dodatku w taki sposób, jakby należały do Spiegelberga, co tylko pogłębia wrażenie, że czytanie i refleksja to „skazy” znamionujące postaci negatywne.

Zamysł przyszłego herszta zbójców o powrocie do rodzinnego domu w akcie I rodzi się w redakcji mannheimskiej nie z przemyśleń inspirowanych lekturą, lecz wskutek utraty źródła dochodu - zapewne wojskowego żołdu, skoro przyczyną nieszczęścia staje się zawarcie pokoju:

Karol. Cóż tam znowu?

Szpigelberg. Jeszcze się pytasz? czytaj tutaj sam ([podaje mu list])

Jeszcze się pytasz? Czytaj, czytaj sam. Już po naszem

rzemiośle, pokój stanąl.

Karol. Pokój?

Szpigelberg. Nieprawdaż? mało się czlek nie obwiesi. Đosturszubienie.

Karol. $\quad$ Teraz zdychaj Moor. Teraz tam pióra bazgrać będą, gdzie pierwej nasz oręż płatal.

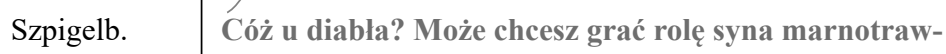
nego? Taki zuch jak ty, co więcej orężem kres po twarzach narobil, niźli trzech pisarzy $\mathrm{w}$ roku przestępnym liter do książki nabazgrało. Fe, wstydź się, nieszczęście nie powinno wielkiego czlowieka tchórzem czynić.

Skądinąd wiadomo, że przeniesienie akcji z połowy XVIII wieku w odległe czasy pokoju wymusił na autorze Dalberg ${ }^{50}$. Aluzje do niedawnej (1756-1763)

49 BTLw 801, op. cit., k. 11r. Transliteracja uwzględnia późniejsze dopiski i wklejki-sygnalizowane pogrubieniem i ramką - lecz spod nich przebija wersja pierwotna: „Pokój? [...] kiedy tak, powracam do mego ojca".

50 Schiller protestował listownie, argumentując, że postaci przeniesione o trzy stulecia w przeszłość okażą się ,zbyt oświecone, zbyt uwspółcześnione” (cyt. za: Klasycyzm niemiecki..., op. cit., s. 138), ale ostatecznie młody autor musiał skapitulować przed doświadczonym dyrektorem teatru. 
wojny siedmioletniej między Prusami i Austrią (włącznie z nazwiskiem poległego w niej generała Schwerina) zastąpiła w redakcji mannheimskiej wzmianka o wojnie polsko-tureckiej ${ }^{51}$. W przekładzie Kamińskiego, przeznaczonym do wystawienia w obszarze działania cenzury austriackiej, oczywiście i ta musiała zniknąćc ${ }^{52}$. Wywołana przez okoliczności polityczno-cenzuralne modyfikacja nie pozostała bez wpływu na konstrukcję i wymowę dzieła. Z jednej strony motywacja osadzona $\mathrm{w}$ warstwie zdarzeń, a nie przemyśleń, zgodnie $\mathrm{z}$ tradycyjną wizją dramatu mogła się wydać bardziej wiarygodna, ale przecież - z drugiej strony - przesunęła myśl bohatera ze sfery idei w krąg spraw materialnych.

$\mathrm{Na}$ domiar złego rozmywa się tutaj aspekt rewolucji społecznej - w wersji kanonicznej dostarczający Moorowi moralnego alibi dla zbójeckiego fachu. Z rozmowy przeprowadzonej w Lasach Czeskich z przedstawicielem enigmatycznie określanej „władzy” odpadła w edycji mannheimskiej tyrada, w której Karol Moor najdobitniej krytykuje „całą obłudę i metody kolonialne feudalizmu" 53 . W ogóle w redakcji mannheimskiej obowiązuje - inspirowana presją rodzimej, niemieckiej cenzury - zasada omijania treści rewolucyjnych i nietykania arystokracji ani duchowieństwa (posłańcem władzy nie jest już Ksiądz, lecz Komisarz - „Der Kommisar”, przez Kamińskiego przethumaczony jako „Osoba sądowa” ${ }^{54}$ ), zaostrzona jeszcze w wersji polskiej, w której kochankę Kosińskiego uprowadza nie sam książę, tylko ,jeden z dworskich"55.

Kochankę Karola natomiast skutecznie uwiódł w tej redakcji tajemniczy zamkowy gość, czyli sam nierozpoznany Karol. Właśnie w tej scenie aktu IV, z której

51 Zob. Neue [...] Original-Auflage, op. cit., s. 54.

52 O przepisach cenzorskich w Galicji i ich wpływie na działalność Kamińskiego zob. B. Maresz, M. Szydłowska, Jana Nepomucena Kamińskiego kłopoty z cenzurą, „Pamiętnik Teatralny” 1988 z. 3-4.

${ }_{53}$ Klasycyzm niemiecki..., op. cit., s. 143. Pominięty fragment w przekładzie Budzyńskiego brzmi tak: „Z pośrodka chmur tajemniczych grzmią słowami dobroci i cierpliwości, a składają z ludzi ofiary Bogu miłosierdzia, jakby o ognistych ramionach Molochowi; nauczają o miłości bliźniego, a przekleństwami wypędzają za drzwi ośmdziesięcioletniego starca bez oczów; wyrzekają na chciwość, a wyludnili Peru za sztaby złota i pogan jak bydło do wozów zaprzęgali. [...] O wy faryzeusze, wy fałszerze prawdy, wy Bóstwa małpy! Przed ołtarzem i krzyżem padacie na kolana, dyscyplinami rozdzieracie ciało na grzbiecie i dręczycie postami. Toż wam się zdaje, że kuglarstwem podobnem nasypiecie piasku do oczów temu, którego wy głupcy wszechwiedzącym zowiecie ", Budzyński, op. cit., s. 94.

54 O tym, że względy religijne zachowywały swą moc nawet w warunkach liberalizacji cenzury politycznej, świadczy fakt, iż jeszcze w pochodzących $z$ lat osiemdziesiątych odpisach teatralnych opartych na przekładzie Budzyńskiego (którego redakcja drukowana jest wierna decyzjom Schillera) Księdza-posłańca władzy z aktu II zastępuje raz znany z redakcji mannheimskiej „Komisarz” (BTLw 1158, op. cit., k. 76r i nast.), a raz... „Mozer” (BTLw 1780, op. cit., k. 58r i n.), który w swej oryginalnej roli dialogowego partnera Franciszka $\mathrm{z}$ aktu V nie pojawia się w żadnym z dostępnych odpisów, gdzie - zgodnie z redakcją mannheimską, ale wbrew tłumaczeniu Budzyńskiego - usunięto całą światopoglądową dyskusję, do jakiej młodszy z braci Moor w obliczu śmierci zaprasza pastora.

55 BTLw 801, op. cit., k. 30v. 
tłumacz zapomniał usunąć Hermana (,przeprowadzonego" tam w skróconej wersji niemieckiej z poprzedniego aktu). Poza tym jednym szczegółem scena jest skróconą (i z nieco większą pruderią rozegraną) wersją redakcji mannheimskiej:

\section{$\underline{\text { Scena } 4}$}

Dawni [tj. Amalia i Herman], Karol. (wstrzymując ją w progu).

Karol. Dokądżeć tak nagle pani?

Amalia. (prawie oniemiała) Boże mój!... to on!

Karol. Przychodzę się pani pożegnać. Lecz cóż znaczy to nagłe twoje pomieszanie? -

Amalia. Idź panie hrabio!.. ale nie, zostań...! O, jakżebym szczę́liwą się zwać mogła, gdybym cię teraz tylko.... gdybym cię nie oglądała!

Karol. Jeżeli moja przytomność rodzi pani w tobie niepokój, więc żegnam cię! (chce odejść)

Amalia. O, idź panie!... jeszcze czas. Daj mi przykład twej stałości, chartu[!] twej duszy... oddal się!

Karol (całuje jej rękę) Twoje drżenie pani pozbawia mnie męstwa. Zostanę przy tobie.

Amalia. Trzebaż ci było wracać tutaj z dalekich krajów, aby zachwiać miłość w mem sercu, która się samej śmierci opierała? (tuląc go ku piersi) O, niechaj ci to Bóg przebaczy!

Karol. ( $\quad \underline{w}$ uścisku $)$ Jeżeli to jest chwila rozłączenia duszy z ciałem, więc śmierć jest najdoskonalszem dziełem Boga!

Amalia. $\quad \mathrm{Tu}-\mathrm{w}$ tym miejscu gdzie ty stoisz, stał on tylokrotnie, a przy jego boku ta, $-\mathrm{która}$ dla niego o niebie i ziemi zapomniała. Tu... tu w tym miejscu zrywał dla mnie róże - a usta jego pałające ogniem miłości składały na moich gorące pocałowania, stojąc wsparty na mojem ramieniu. (chwila obopólnego rozczarowania - Karol jak bezprzytomny całuje ją w usta, potem jak szalony odskakuje od niej)

Amalia (omdlała prawie na ławce) Teraz skaż mnie Karolu!... przysięga moja złamana!

Karol. Jakaś furia piekła musi czuwać nade mną, gdy jestem tak szczęśliwy! (wpatruje się w nia chwile)

Amalia. (ujrzawszy pierścień na swojej dłoni-zrywa się nagle) Tyśs tu jeszcze, na palcu występnej!.. Miałbyś być dzisiaj widzem jak Amalia z przysiąg swoich szydzi?.. Precz! precz stąd! (ściąga go i podaje Karolowi) Weź go!.. weź!... A z nim wszystko co mi było najświętszem... najdroższem..! - mego Karola....!

Karol. Boże! i to jest ten sam pierścień, który jej dałem na znak związku naszego? Przepadnij więc miłości! Mam znowu mój pierścień! -

Amalia (nieco zbudzona) Przebóg!.. co tobie jest? cały pobladły?.

Karol ... Nic... nic..! (n..s.) Jeszcze jestem mężem! - (zdejmuje z palca swój pierścień cały dziki - i wkłada go Amelii) Przyjmże więc ten, - słodka ty furyo serca mego! a z nim wszystko co mi było najświętszem... najdroższem!... moją Amalią! -

Amalia. (zerwawszy się) Twoją Amalią?.

Karol ( $\underline{\text { z boleścia })}$ O!.. była to miła dziewczyna, - wierna, czysta jak anioł. Dyament dała mi na pożegnanie, a ja jej brylant zostawiłem na znak naszego związku. Słyszała 
żem umarł, a jednak dotrzymała mi wiary - nawet umarłemu; lecz gdy posłyszała że żyję, stała się wiarołomną! O tak, Amalia jest bardzo teraz nieszczęśliwą! -

Amalia (wpółmartwa) Nieszczęśliwą że ciebie odrzuciła?..

Karol. ( $\quad$ dziko $)$ Ponieważ mnie w podwójnej postaci ściskała.

Amalia (nieco płocha) Czy wszystkie są równie nieszczęśliwemi co ciebie kochają - a Amalia się zowią?

Karol. Wszystkie!.. kiedy rozumieją że Anioła mają przy sobie, a zbójcę w swem objęciu znajdują! Moja Amalia jest nieszczęśliwą. (bierze jej rękę i pokazuje swój pierścień)

Amalia. Ah!...

Karol. Płacz! płacz teraz sama nad sobą! (wybiega)

Amalia. (biegnie za nim) Karolu to ty?.. o mój Karolu ${ }^{56}$ !

Inaczej niż w wersji kanonicznej, dochodzi tu do pełnego rozpoznania, któremu służą wymienione niegdyś pierścienie. Co prawda według relacji Franciszka z I aktu Karol miał podarować ten klejnot jakiejś rozpustnicy, która następnie zastawiła go czy może sprzedała Żydowi, ale z dialogu nie wynika jednoznacznie, że pierścień znalazł się ostatecznie w jego posiadaniu i może stanowić dowód zdrady. Tę niejasność usuwała edycja mannheimska, w której upraszczające poprawki służyły zarazem wzmocnieniu scenicznego efektu. Subtelną grę niedomówień i przemilczeń redakcji pierwotnej zastąpiło tu dobitne rozwiązanie, które - zgodnie z tradycyjnymi regułami dramatu i sceny - aktywizowało dramatycznie rekwizyt wcześniej przez Schillera zapomniany. W pierwszym opracowaniu tej sceny występujący incognito Karol opowiada rezydentce zamku o jakiejś swojej Amalii, a podejmująca go wychowanka zmarłego rzekomo hrabiego wspomina nienazwanego z imienia ukochanego. W rezultacie Karol ucieka, ponieważ czuje się niegodny dawnej kochanki. W edycji mannheimskiej rozpoznanie prowadzi do rozstania, które obciąża Amalię, bo „zdradziła” Karola, to znaczy: uległa mu, kiedy występował w przebraniu.

W rysunku A mali i daje się zauważyć przede wszystkim podmiana jednego z budulców postaci. Miejsce pierwotnie charakteryzującego Amalię śpiewu zajmuje w edycji mannheimskiej obraz. Co prawda partie śpiewane ${ }^{57}$ wyeliminowano nie tylko z tekstu roli wychowanki hrabiego, ale jedynie w jej przypadku mają one substytut wizualny - symboliczny atrybut przeniesiony również do przekładu Kamińskiego - kwiat róży, nieobecny w innych teatralnych opracowaniach:

56 BTLw 801, op. cit., k. 37r-38r.

57 „Pożegnanie Andromachy i Hektora” śpiewane przez Amalię staremu Moorowi jako wspomnienie Karola w scenie drugiej aktu II i śpiew Amalii w ogrodzie, poprzedzający wejście Franciszka w pierwszej scenie aktu III, a także pieśn Karola o „spotkaniu zmarłych” - Brutusa i Cezara - ze sceny piątej aktu IV oraz śpiewy zbójców w II i IV akcie. 


\section{Zmiana.}

Pokój sypialny hrabiego Max. Moor.

Hrabia, Amalia.

Scena 3.

(Hrabia drzemie w fotelu, Amalia przy nim wpatrując się)

Amalia. Jak miły i czcigodny starzec! tak właśnie świętych malują, - włos srebrny skroń mu okrywa, - nie, nie mogę się na niego gniewać. (skubie kwiat róży i rzuca na niego). Śpij słodko w woni różowej, wpośród róż niech ci się twój drogi Karol objawia. Niech róże wieńczą dni wasze, ja w rozmarynie chcę usnąć, usnąć na wieki.

Hrabia (w śnie) Mój Karolu!... Karolu!.. mój kochany Karolu!

Amalia. Anioł wysłuchał prośbę jego; o jak słodko oddychać powietrzem, z którym się imię jego miesza!

$[\ldots]$

Hrabia. (wstając z krzesła) Cóż to ja widzę? Róże woniejące obok mnie. Niewinna dziewczyno, Różami obsypujesz mordercę twojej miłości.

Amalia. O! niechaj zawsze cię one zdobią. Tyś kochał mego Karola.

Hrabia (zsuwajac firanke z obrazu) Znasz ty ten obraz ${ }^{58}$ ?

Idąc za wskazówkami zawartymi w słowach Amalii, spośród możliwych znaczeń symbolicznych róży wybrać tu chyba należy odrodzenie przez miłość silniejszą od śmierci ${ }^{59}$, spełnione dzięki ofierze samej bohaterki, która własny los widzi już $\mathrm{w}$ symbolice rozmarynu kojarzonego $\mathrm{z}$ krainą zmarłych ${ }^{60}$. Ten dziwny obrzęd Amalia odprawia chwilę przed wejściem przebranego Hermana z fałszywą wieścią o śmierci Karola, która w tym kontekście wygląda na ironię losu - odpowiedzią na prośbę o wieńczenie różami dni ukochanego staje się doniesienie o jego śmierci. Wolno ten chwyt postrzegać jako typową dla niemieckiej odmiany

58 BTLw 801, op. cit., k. 18v-19r. Tekst jest tutaj dość wiernym przekładem redakcji mannheimskiej, zob. Neue [...] Original-Auflage, op. cit., s. 50-51. Zapowiedź kwietnego rekwizytu pojawia się już w otwarciu sceny trzeciej aktu I, zamienionej tu miejscami z drugą (zapewne w celu uniknięcia zmiany otwartej), co pociągnęło za sobą konieczność innego zainicjowania rozmowy, której Amalia wolałaby uniknąć (jak wszystkich spotkań z młodszym z braci Moor). Pierwotnie Schiller zaplanował w tym miejscu najście dziewczyny przez Franciszka w jej własnym pokoju - w przekładzie redakcji kanonicznej: „W zamku Moorów. Pokój Amalii. Franciszek. Amalia. FRANCISZEK Odwracasz się, Amalio? Czyżem mniej godny jak ten, którego ojciec przeklął?” (Budzyński, op. cit., s. 40). Przy zmianie kolejności scen natomiast trzeba było jakoś uzasadnić wejście bohaterki do tej samej komnaty, z której przed chwilą wyszedł stary Moor, i w której pozostały na scenie Franciszek monologuje na temat przewartościowania więzów krwi. Amalia wchodzi więc mimowolnie, skupiona na innej czynności, co w odpisie przekładu Kamińskiego wygląda tak: „Franciszek, Amelia (wchodzi rwiąc[!] kwiaty). Franciszek. Cóż ei te biedne kwiaty zawinily? (Amelia odwraca się) Odwracasz się Amelio?.. czyżem mniej godny jak ten którego ojciec przeklął?” (BTLw 801, op. cit., k. 7r) - a w wersji niemieckiej jeszcze dosadniej, gdyż tam Amalia, początkowo snując się w tle, dodatkowo jeszcze depcze rozerwany bukiet stopami - ,zertritt ihn mit Füßen” (Neue [...] Original-Auflage, op. cit., s. 15).

59 Zob. H. Biedermann, Leksykon symboli, przeł. J. Rubinowicz, Warszawa 2001, s. 310.

60 Zob. P. Kowalski, Kultura magiczna. Omen, przesą, znaczenie, Warszawa 2007, s. 499. 
dramy - zwanej tragedią losu - trywializację motywu o starożytnym rodowodzie. $\mathrm{W}$ tragediach Sofoklesa postaci w mniejszym lub większym stopniu występne odbierają nowiny pozornie spełniające ich życzenia wyrażone w bluźnierczych nierzadko modlitwach - i właśnie ów pozór, fałszywa wartość lub błędna interpretacja nadchodzącej wieści sprawiają, że wejście posłańca bezpośrednio po modlitwie zyskuje status przewrotnej odpowiedzi nieobecnych, a może tylko niewidocznych na scenie bogów ${ }^{61}$. W przeformułowanej przez Kamińskiego scenie Zbójców wejście przebranego Hermana mogłoby mieć taki lub zbliżony sens jedynie w kontekście późniejszych zmagań Franciszka z własnym snem o Sądzie Ostatecznym oraz jego sprzeciwu wobec istnienia Boga.

Akurat Franciszek, którego w teatralnym przekładzie nie byłoby trudno przerobić na cynicznego łotra, w wersji Kamińskiego pozostał dość złożoną postacią, choć w kształcie nie całkiem Schillerowskim. Stracił przede wszystkim siłę charakteru. Dodatkiem tłumacza (lub też późniejszych jego teatralnych korektorów, których poprawki przeniknęły do odpisu) jest rozbieżność między filozoficzną postawą a praktycznym działaniem Franciszka, gdyż o ile podczas formułowania swoich śmiałych tez bohater zachowuje spokój, o tyle przystępując do działania traci pewność siebie. Dyskretne i pozornie drobne przesunięcia - nie wiadomo, czy przeprowadzone ze świadomością konsekwencji i czy we wszystkich przypadkach przez Kamińskiego, a nie na przykład w trakcie późniejszych przepracowań roli akcentują wewnętrzny konflikt w umyśle i duszy bohatera, który w ciągu akcji dramatu narastać będzie w coraz silniejszych i coraz bardziej nieuniknionych konfrontacjach. Ewolucja postaci przyjmie ostatecznie przebieg nieco inny niż u Schillera.

Schillerowski „kanoniczny” Franciszek w trzech monologach i dyskusji z pastorem Moserem dojrzewa do kolejnych decyzji i działań. Pierwszy monolog, w akcie I, deprecjonujący więzy krwi i eksponujący przypadkowość aktu poczęcia oraz narodzin, wyzwala gotowość do usunięcia starszego brata. Rozważania o analogiczności przedłużania i skracania życia w monologu drugim z początku aktu II dostarczają motywacji do podjętej wkrótce próby pozbycia się starego Moora. Monolog trzeci, wypowiadany w akcie IV po wydaniu Danielowi rozkazu zgładzenia tajemniczego hrabiego, w którym Franciszek zaczyna domyślać się brata, uzasadnia decyzję poprzez powtórzenie wątków z poprzednich wystąpien. Tak krystalizuje się postać nazwana przez Marię Janion ,pierwszym wielkim autentycznym nihilistą epoki nowożytnej”’2. Po dyskusji z pastorem Moserem - poprzedzonej ze strony Franciszka rozpaczliwą negacją istnienia Boga, zawierającą nutę buntu przeciwko własnej nieśmiertelności - następuje chwilo-

${ }^{61}$ W Królu Edypie poseł z Koryntu przynosi wieść o śmierci przybranego ojca Edypa zaraz po tym, jak Jokasta zaniosła do Apollina prośby o potwierdzenie jej sceptycyzmu wobec przepowiedni; w Elektrze wejście posłańca oznajmiającego - niezgodnie z prawdą - że zginął Orestes, przypada bezpośrednio po bluźnierczej modlitwie Klitajmestry o śmierć syna.

62 Zob. M. Janion, Przewrotny Prometeusz, [w:] eadem, Prace wybrane, t. 1: Goraczka romantyczna, Kraków 2000, s. 218. 
we załamanie połączone $\mathrm{z}$ próbą modlitwy, po czym bohater $\mathrm{z}$ dumą zawraca $\mathrm{z}$ drogi skruchy i pokuty, by z godnością oddać się mocom piekielnym: „zwycięstwa niebo nie odniesie i piekło ze mnie szydzić nie będzie"63. Ostatecznie i to wystąpienie popycha Franciszka do działania zgodnego z jego filozofią - do samobójstwa.

Inną drogę funduje Franciszkowi edycja mannheimska, jeszcze inną - odpis przekładu Kamińskiego. W obu opracowaniach tekstu dwa pierwsze monologi bohatera pozostały na swoich miejscach $-\mathrm{w}$ formie skróconej, ale $\mathrm{z}$ zachowaniem najważniejszych sensów. Jednak już w następstwach monologu pierwszego doszło u Kamińskiego do drobnych, choć znamiennych przesunięć. Wciąganiu w intrygę Hermana towarzyszą tu nieobecne w redakcjach kanonicznej i mannheimskiej gesty zdradzające nerwowość - Franciszek mówi najpierw „w roztargnieniu”, po chwili „z uśmiechem radości”, a wreszcie „biorąc go [Hermana] za rękę”" ${ }^{44}$ czyli buduje więź emocjonalną zamiast podstępnie grać na ambicji i dumie przyszłego wspólnika, któremu - znów inaczej niż w obu niemieckich wersjach - nie podsuwa fałszywych powodów do zemsty na Karolu.

Trzeci zaś monolog pojawia się w polskim przekładzie w zmienionej funkcji, gdyż nie uzasadnia podjętej wcześniej decyzji zabójstwa, a raczej tak samo jak poprzednie ma do niej dopiero doprowadzić. Wygląda to na oryginalny zamysł Kamińskiego, choć inspirowany wcześniejszymi teatralnymi modyfikacjami. W edycji mannheimskiej, podobnie jak w późniejszym przekładzie Kamińskiego, Franciszek nie wyręcza się w dziele zabójstwa starym sługą ani nikim innym, ma to jednak w tekście polskim inną przyczynę niż w przeróbce niemieckiej.

Redakcja mannheimska najpierw rozbija drugi monolog Franciszka na trzy części, przerywane wejściami Daniela, po czym ostatnią partię dialogu tych postaci - w której sługa zgodnie z wersją kanoniczną powinien odebrać rozkaz zabicia tajemniczego hrabiego - zastępuje rozmową Franciszka z przywołanym Hermanem, najwyraźniej typowanym do wypełnienia owej misji. Powtarza się porządek znany z aktu I - po przemyśleniach prowadzących do decyzji następuje sprowadzenie wykonawcy. Tym razem jednak rozmowa, która ze względu na przybrany kierunek może stanowić zapowiedź rychłego wyznania prawdy przed Amalią, nie przebiega zgodnie z planem Franciszka - w wersji mannheimskiej, bo w wersji Kamińskiego (przynajmniej tej znanej z odpisu) w ogóle do niej nie dochodzi, czyli decyzja dokonania czynu samodzielnie nie zostaje wymuszona przez okoliczności.

Franc. Dosyć!.. dosyć!.. idź i przwaj mi Hermana (Daniel odchodzi.) To on!.. to Karol!.. Musi zginąć! - idzie tylko o spieszne wykonanie. (쏘śli) A gdybym też sam niespodzianie... niewidziany, topil nim szylet-izamordowal? ${ }^{65}$

63 Budzyński, op. cit., k. 174.

64 BTLw 801, op. cit., k. 16v-17r.

65 BTLw 801, op. cit., k. 36r. 
Początek - wiążący monolog z poprzedzającym go dialogiem i zapowiadający spotkanie z Hermanem (tutaj niezrealizowane) - odsyła do edycji mannheimskiej ${ }^{66}$, rozszerzonej o zaczerpnięte $\mathrm{z}$ poprzedniego (drugiego) monologu rozpoznanie i życzenie zgładzenia rozpoznanego brata. Następna partia monologu pochodzi już z wersji kanonicznej:

Otóż i całe piekło furyj wokoło tego słowa skaeze. - Głupstwo przeklęte! którym mamki i piastunki wyobraźnię naszą przekręcają..., straszydłami i na mózgach naszych obrazy sądu ostatecznego wyciskają. Szaleństwo! Natura mniej jednego człowieka zapomniała stworzyć niemowlęcia nie powito przy narodzeniu należycie... i otóż chińskie cienie zniknęły. Było coś, a jest nic. - Nie wszystkoż to jedno, jakby było nic, i jest nic ${ }^{67}$.

Po niej zaś następuje dość swobodna parafraza redakcji mannheimskiej, którą roboczo można by przełożyć mniej więcej tak:

Chcę się odważyć (podą̇a zdecydowanym krokiem do końca sceny, nagle zatrzymuje się, strasznie ostabiony) Kto się za mną podkrada? (Przewracając oczami) twarze, których nigdy nie widziałem - [...] Strach wiruje w moich włosach, miażdży moje kości. (upuszcza sztylet) Nie jestem tchórzem - jestem zbyt łagodny - tak! tak jest! - To są drżenia umierającej cnoty. - Podziwiam je. - Muszę być potworem, jeśli chcę podnieść rękę na rodzonego brata - Nie! nie! nie! Oddal się! - Tym reliktom ludzkości we mnie chcę oddać honory. - Nie chcę zabijać.

- Wygrałaś, naturo. - Czuję też coś, co równa się miłości. - Niech on żyje ${ }^{68}$ !

W przekładzie Kamińskiego jednak wyraz kulturowych i naturalnych hamulców zastąpiony zostaje początkami obłędu:

A więc dalej Franciszku! - śmiało! (szuka sztyletu - odchodząc) Kto tu!.. kto tu się za mną skrada!.. Twarze, jakich nigdy jeszeze nie widziałem... strach mnie całego przejmuje... mróz śmiertelny seree przenika... tysiące głosów powtarza: bratobójco!.. bratobójco!... (rzuca sztylet) Nie! precz!.. precz!... nie!.. nie!.. (ucieka) ${ }^{69}$

66 „Genug! Geh! Lauf! Spring! Hole mir Herman. (Daniel ab)”, Neue [...] Original-Auflage, op. cit., s. 105 - i dalej, po wyjściu Hermana: „es gilt einen raschen Entschluß! - Wie? wenn ich selbst hinginge - ihm den Degen in den Leib bohrte hinterrücts?”, ibidem, s. 111.

67 BTLw 801, op. cit., k. 36r.

68 Przeł. M. D. „Ich wills wagen (er geht starken Schritts nach, dem Ende der Bühne, bleibt aber plötzlich in schreckhafter Erschlaffung stehen) Wer schleicht hinter mir? (die Augen grätzlich rollend) Gesichter, wie ich noch keine sah - [...] Schrecken greiselt in meinen Locken - Durch meine Knochen Zermalmung. (er läßt den Dolch aus dem Kleide fallen) Feig bin ich nicht - allzuweichherzig bin ich - Ja! so ist es! - Es find die Zuckungen der sterbenden Tugend - Ich bewundere sie - Ein Ungeheuer müßt ich sein, wollt ich die Hand legen an meinen leiblichen Bruder - Nein! nein! nein! das sei ferne! - Diese Reliquien der Menschheit in mir will ich Ehren halten - Ich will nicht tödten - Du hast gesiegt, Natur - auch ich fühle noch etwas, das der Liebe gleicht - Er lebe!”, Neue [...] Original-Auflage, op. cit., s. 111-112.

69 BTLw 801, op. cit., k. 36r-36v. 
W tym momencie załamuje się linia losu Franciszka, u Kamińskiego poprowadzona zgodnie z klasycystyczną zasadą punktu kulminacyjnego ${ }^{70}$. Pozostałości scen okalających w redakcji kanonicznej rozmowę z pastorem Moserem - zakwestionowanie istnienia Boga i bluźniercza modlitwa - są w wersji Kamińskiego już tylko odcinkami drogi zstępującej ku katastrofie. Samej zaś katastrofy bohater nie przyjmuje z taką godnością, na jaką zdobywa się jego Schillerowski pierwowzór.

\section{TROJAKIE ZAKOŃCZENIE}

W miejscu, w którym w redakcji kanonicznej przypada samobójcza śmierć Franciszka, zachowany odpis przekładu Kamińskiego serwuje zagadkę filologiczną - u dołu strony 46v znajduje się jedyna w całym dokumencie wklejka wychodząca poza powierzchnię karty. Zapis tekstu utrwalonego na tej powierzchni $\mathrm{w}$ transliteracji dyplomatycznej przedstawia się tak:

Daniel. Boże w niebiosach! cały zamek w płomieniach!

Franc. (odpasując szpadę.) Weź to żelazo - prędzej, przeszyj pierś moją! - prędzej... spiesz się! e

Daniel. Boże! Zachowaj mnie!.. ja nikogo nie posłałbym do nieba, tymbardziej do... (ucieka)

Francisz. Do piekła!.. chciałeś powiedzieć. W samej rzeczy -

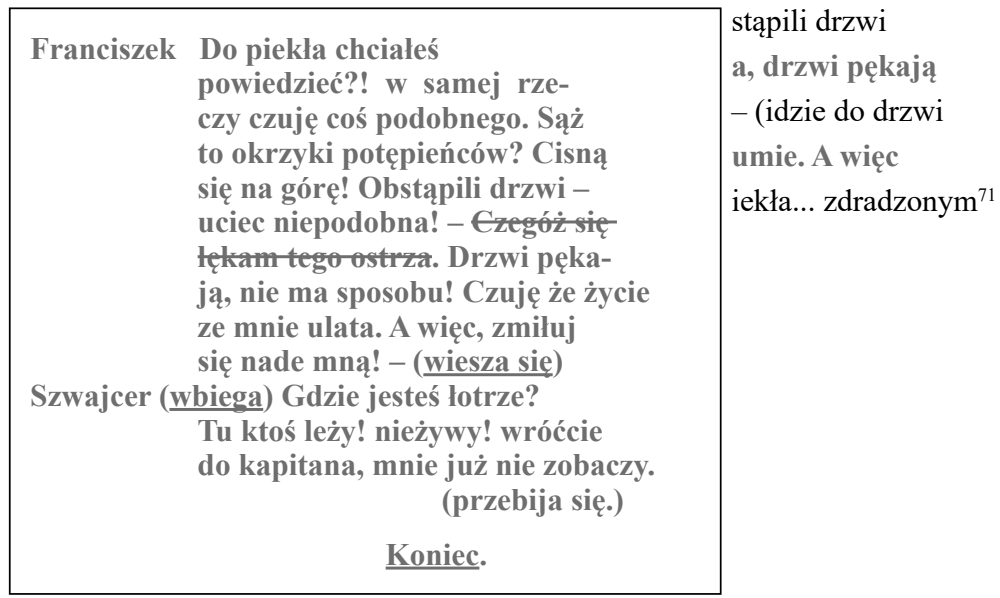

70 Według O. Dobijanki-Witczakowej, moment zwrotny w karierze Franciszka, od którego linia jego działania zmierza ku katastrofie, przypada wcześniej - w chwili podjęcia decyzji o pozostawieniu przy życiu starego Moora i świadka zbrodni, Hermana, zob. eadem, Wstęp, [w:] F. Schiller, Zbójcy, przeł. F. Konopka, BN II 30, Wrocław 1986, s. XLIX.

71 BTLw 801, op. cit., k. 46v. 


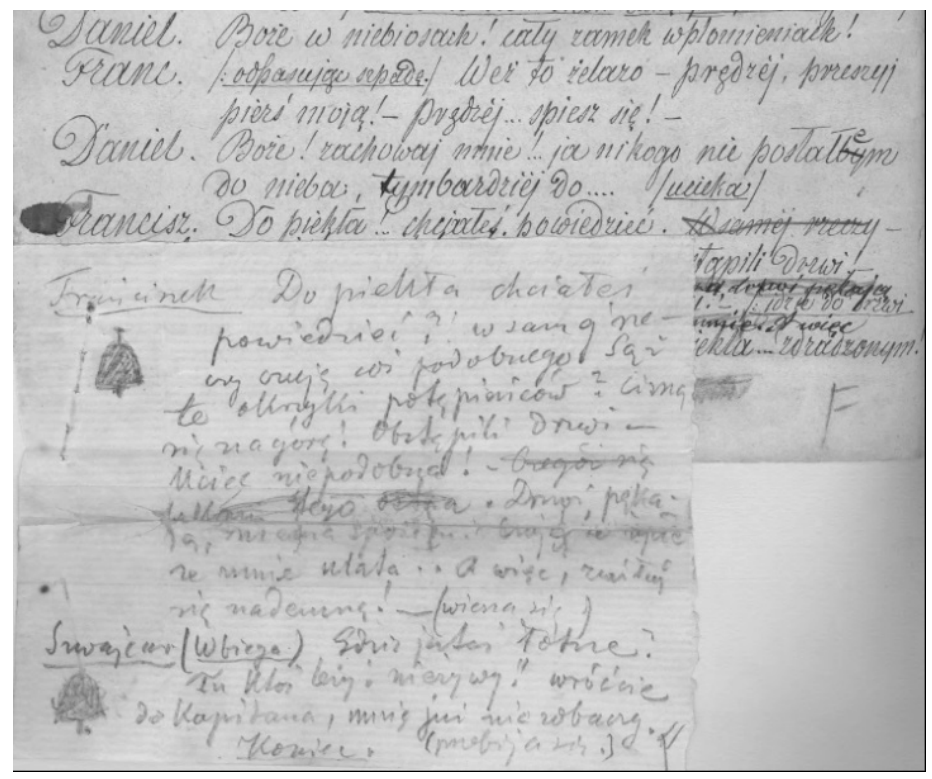

Dolny fragment karty 46v odpisu przekładu J. N. Kamińskiego, Biblioteka Śląska, BTLw, sygn. 801

Pod wklejką znajdują się zapewne didaskalia zgodne z redakcją mannheimską, w której Franciszek jeszcze nie ginie, tylko „skacze w płomienie”72, ścigany przez wdzierających się do zamku zbójców.

Zdarzyło się zatem w dziejach inscenizacji dramatu w przekładzie Kamińskiego po roku 1864, że postanowiono zakończyć przedstawienie nie tyle śmiercią Franciszka, ile przyspieszonym zamknięciem pierwszej sceny aktu IV z wersji kanonicznej. Pomysł wydaje się chybiony - w mniejszym nawet stopniu z tego powodu, że czyniąc głównym bohaterem Franciszka, pozostawia nierozwiązany wątek Karola oraz niepewność względem losu starego Moora i Amalii, ale przede wszystkim dlatego, że samobójczą śmierć Schweizera - nieprzygotowaną, niekonieczną i przez to nietragiczną - czyni ważniejszą od śmierci chwilowego zwycięzcy, który tragicznie zbłądził.

Następne karty dokumentu, oznaczone numerami 47-49, dowodzą, że i ten przekład wystawiano kiedyś z dodanym zakończeniem odpowiadającym redakcji kanonicznej. Zawierają bowiem skrót akcji ostatnich scen V aktu (rozmowę zamaskowanego Karola z uwolnionym hrabią Moorem, powrót zdobywców zamku z Amalią, śmierć starca, przypomnienie przysięgi Karola i zabicie przezeń dawnej

72 Dosłownie: ,er springt in die Flamme”, Neue [...] Original-Auflage, op. cit., s. 146. 
kochanki oraz pożegnanie dotychczasowego herszta z bandą zbójców) - skrót niewiadomego pochodzenia (niezgodny z przekładem Budzyńskiego), odnotowany charakterem pismem innym niż podstawowe i innym niż to, którym dokonywano poprawek na pozostałych kartach czy wklejkach.

Trzecia wersja zakończenia - zapisana podstawowym dla dokumentu charakterem pisma - zaczyna się od karty z numerem 50 i stanowi bezpośrednią kontynuację akcji przerwanej na stronie 46v (zamkniętej wklejką). Zgodnie z redakcją mannheimską tekst na stronie 50r zaczyna się od zmiany dekoracji - przeniesienia miejsca akcji na leśną polanę, gdzie po paru kwestiach okaże się, że w tej wersji dramatu Franciszek... przeżył! Dał się pojmać i oto, przywiedziony przez zbójców Karola, staje przed obliczem ojca i brata. Przekład Kamińskiego, ponownie w skróconej wersji, dość wiernie jednak oddaje scenę sądu nad złoczyńcą:

(słychać z dala okrzyki zbójców - widać pochodnie).

Starzec. Biada mi! Cóż to za chałas[!] i wrzawa?.. To zapewne katy mojego Franciszka... prowadzą go tutaj aby mu wydrzeć życie!

Karol. (n.s.) Boże w Niebiesiech! wysłuchaj modlitwę zbójcy, uczyń go nieśmiertelnym, nie odbieraj mu życia zaraz przy pierwszym uderzeniu, a każdy raz zadany ręką mściciela, niech przedłuża konanie jego.

\section{Scena 3}

Dawni, Zbójcy, Franciszek w łańcuchach)

Szwajcer. Zwycięstwo kapitanie! Oto jest ten łotr, dotrzymałem słowa.

Kosiński. Zamek jego w perzynę obrócony, a pamięć jego imienia na wieki zaginęła! (pauza)

Karol. (zbliża się do Franc.) Znasz ty mnie?...

Franc. (milczy osłupiały)

Karol. (wskazuje starca) Znasz ty tego?

Francisz. Ha! mój ojciec! -

Starzec. (z pogardą) Idź, niechaj ci Bóg tak przebaczy, jak ja ci wszystko przebaczam w tej chwili! -

Karol (wściekle) Lecz moje przekleństwo chwyci twe przebaczenie w locie, i zwróci[!] z drogi zbawienia. Znasz ty tę wieżę?..

Franc. Więc aż do tego stopnia nienawiść ku mojemu ojcu zaślepiła cię?... ${ }^{73}$

Herman. Brawo! Przecież i tu diabeł nie zaniedbuje swojego klienta, i w ostatniem wspiera go kłamstwie.

Karol. Dosyć; - tego starca odprowadzić w głąb lasu, tu nie łez ojcowskich potrzeba!

73 Niezbyt szczęśliwie oddana w przekładzie ta kwestia Franciszka brzmi w rzeczywistości tak: „(gwaltownie do Hermana) Co potworze? Aż do tej wieży doprowadziła twoja rodowa nienawiść mojego ojca?"/ „(heftig zu Herman) Was Ungeheuer? Bis zu diesem Thurm verfolgte dein Familienhass meinen Vater?", Neue [...] Original-Auflage, op. cit., s. 151, przeł. M. D. 
Starzec. (którego zbójcy odprowadzają) Miejcież litość dla obłąkanego dziecięcia! ${ }^{74}$ -

Karol. Zbójcy przystąpcie tu bliżej! Jako pełnomocnik sądu ostatecznego, stawam tutaj aby wydać wyrok; grzesznicy są sędziami, a ja na ich czele. Któż obok tego zbrodniarza nie stoi jak anioł czysty? Powiedzcie, czy w waszym kole znajduje się aby jeden jemu równy... kto się z was poczuwa że jest winniejszym od niego niech odrzuci swój sztylet od siebie. - (zbójcy rzucaja sztylety) Ciesz się Franciszku, tyś dziełem twoim z rabusiów aniołów porobił; ale jeszcze wam na jednym zbywa sztylecie. (dobywa sztylet, zamienia[!] go na Franciszka, pauza - potem rzuca) Jego matka i mnie na świat wydała, wy go osądźcie - ja nie powinienem. Szwajcer, Kosiński, wy go osądźcie!

Wszyscy. Do wieży z nim... do wieży!

Francisz. (tuląc się do Karola) Wybaw mnie z rąk morderców!

Karol. Tyś mnie ich naczelnikiem uczynił! (Franciszek odsk.) Będziesz-że mnie jeszcze prosił?...

Zbójcy. (

Karol. Synu ojca mojego! ty mi moje niebo ukradłeś, przebaczam mojemu bratu! (ściska go) Ale ojcobójcy nigdy! - Precz z nim do piekła! -

Zbójcy. (porywają Franciszka, i wrzucają do wieży)

Karol. Już skończyłem, dzięki ci niepojęty Boże! (woła) Przyprowadźcie tu tego starca ${ }^{75}$ !

Dalej już akcja toczy się zgodnie z redakcją kanoniczną. Ten wariant - ze sceną sądu nad ocalałym Franciszkiem, która wielkiej kreacji „przewrotnego Prometeusza"76 odbierała godność, sponiewierawszy go na koniec jak pospolitego zbrodniarza - stosowano także $w$ inscenizacjach opartych na przekładzie Budzyńskiego $^{77}$, którego podstawą - w autoryzowanym wydaniu - była przecież kanoniczna redakcja autorska. Wśród inscenizacyjnych pomysłów warto jednak odnotować również dążenie przeciwne - zaplanowane w jednym z zachowanych egzemplarzy, w którym Franciszek nie wiesza się, lecz z dumą prowokuje własną egzekucję: „leci do okna, staje w niem, w tej chwili pada kilka strzałów, jeden z nich go zabija, pada w tył na ręce wlatujących zbójców - oni go składają na ziemi krzycząc: «Hurrah!»»78.

74 Tej kwestii Moora nie ma w redakcji mannheimskiej, zob. Neue [...] Original-Auflage, op. cit., s. 151.

75 BTLw 801, op. cit., k. 50v-51v.

76 Formuła M. Janion, zob. eadem, op. cit.

77 BTLw 1780, op. cit., k. 116r-118v.

78 BTLw 1158, op. cit., k. 16v. 